\title{
RETRACTION of "Tumor necrosis factor alpha gene $-308 G>A$ polymorphism association with the risk of esophageal cancer in a Han Chinese population" by H. Zhao, H.W. Zhang, T. Zhang and X.M. Gu - Genet. Mol. Res. 15 (2): gmr.15025866 DOI: http://dx.doi.org/10.4238/gmr.15025866
}

\author{
Genet. Mol. Res. 15 (4): gmr.150458661 \\ Published October 7, 2016 \\ DOI http://dx.doi.org/10.4238/gmr.150458661 \\ Copyright (C) 2016 The Authors. This is an open-access article distributed under the terms of \\ the Creative Commons Attribution ShareAlike (CC BY-SA) 4.0 License.
}

The retracted article is:

Zhao H, Zhang HW, Zhang T and Gu XM (2016). Tumor necrosis factor alpha gene -308G > A polymorphism association with the risk of esophageal cancer in a Han Chinese population. Genet. Mol. Res. 15: gmr.15025866.

Two major concerns were found in this article. Firstly, it was found to be substantially equal to the article "Tumor necrosis factor-alpha gene $-308 \mathrm{G}>\mathrm{A}$ polymorphism alters the risk of hepatocellular carcinoma in a Han Chinese population" published in the Diagnostic Pathology Diagnostic Pathology (2014) 9: 199, by Feng et al.; licensee BioMed Central. 2014 - DOI: 10.1186/s13000-014-0199-3.

Secondly, the authors do not discuss limitations of their approaches in the discussion. The discussion is largely an elaboration of the literature in the introduction part. However, even in that context, the discussion does not appropriately review the literature and there are frequent references to conclusions that are not supported by the cited literature.

The GMR editorial staff was alerted and after a thorough investigation, there is strong reason to believe that the peer review process was failure. Also, after review and contacting the authors, the editors of Genetics and Molecular Research decided to retract this article in 
accordance with the recommendations of the Committee on Publication Ethics (COPE). The authors and their institutions were advised of this serious breach of ethics.

\section{Link to original paper}

Genetics and Molecular Research 15 (4): gmr.150458661 